\title{
The morphometric affinities of Apis cerana of the Hindu Kush and Himalayan regions of western Asia ${ }^{1}$
}

\author{
Sarah E. RADLOFF ${ }^{a *}$, Randall HEPBURN ${ }^{\mathrm{b}}$, Stefan FUCHS ${ }^{\mathrm{c}}$ \\ a Department of Statistics, Rhodes University, Grahamstown, 6140, South Africa \\ b Department of Zoology and Entomology, Rhodes University, Grahamstown, 6140, South Africa \\ c Institut für Bienenkunde, 61440 Oberursel, Germany
}

Received 30 April 2002 - Revised 21 May 2004 - Accepted 28 May 2004

Published online 31 January 2005

\begin{abstract}
A multivariate morphometric analysis of Apis cerana populations of the Hindu Kush in Afghanistan and Pakistan and of Kashmir and Himachal Pradesh in India revealed two statistically distinct morphoclusters, a Hindu Kush/Kashmir group and a Himachal Pradesh group. High intercolonial variances at three localities are associated with regions of major climatic zone change, hence ecological instability.
\end{abstract}

Apis cerana / honeybees / morphoclusters / western Asia

\section{INTRODUCTION}

The relationships of Apis cerana Fabricius populations of the Hindu Kush in western Asia to their more easterly Himalayan neighbours have long eluded honeybee morphometricians because of a paucity of specimens available for analysis. In the circumstances, both Maa (1953) and Ruttner (1988) simply concluded that these bees could not be distinguished from those of southwestern China. Data from the Institut für Bienenkunde at Oberursel for A. cerana of the Hindu Kush of Afghanistan and Pakistan (Ruttner, 1988) coupled with those from neighbouring northern India (Hepburn et al., 2001) now allow a conjoint multivariate morphometric evaluation of these geographically contiguous populations in the southern Himalayan region. Here we report the results of such analyses.

\section{MATERIALS AND METHODS}

\subsection{Honeybees}

Morphometric data for worker honeybees of Apis cerana were obtained from two sources: (1) those for Afghanistan and Pakistan and a few localities in India came from the Ruttner/Oberursel database (Ruttner, 1988); (2) those for most of northern India from a southern Himalayan database (Hepburn et al., 2001). A total of 902 bees from 68 colonies at 16 localities was used in the morphometric analysis. The localities, their coordinates, altitudes, sample sizes and data sources are indicated in Table I and mapped in Figure 1.

\subsection{Morphometric measurements}

Twenty-seven morphological characters common to both the Ruttner/Oberursel and southern Himalayan databases were utilized in the present

* Corresponding author: s.radloff@ ru.ac.za

${ }^{1}$ Manuscript editor: Walter S. Sheppard 
Table I. Distribution of the localities, coordinates, altitudes, sample sizes and data sources analysed.

\begin{tabular}{|c|c|c|c|c|c|}
\hline \multirow[t]{2}{*}{ Locality } & \multirow[t]{2}{*}{ Coordinates } & \multirow{2}{*}{$\begin{array}{l}\text { Altitude } \\
\text { (m) }\end{array}$} & \multicolumn{2}{|c|}{ Sample sizes } & \multirow{2}{*}{$\begin{array}{c}\text { Data } \\
\text { source }\end{array}$} \\
\hline & & & colonies & bees & \\
\hline \multicolumn{6}{|l|}{ Afghanistan } \\
\hline 1. Ahangaran & $34.30 \mathrm{~N}, 64.51 \mathrm{E}$ & 2062 & 2 & 20 & Oberursel \\
\hline 2. Kabul & $34.31 \mathrm{~N}, 69.08 \mathrm{E}$ & 1795 & 2 & 40 & Oberursel \\
\hline 3. Bidiwa & $34.56 \mathrm{~N}, 70.22 \mathrm{E}$ & 2206 & 4 & 69 & Oberursel \\
\hline \multicolumn{6}{|l|}{ Pakistan } \\
\hline 4. Peshawar & $34.00 \mathrm{~N}, 71.32 \mathrm{E}$ & 317 & 7 & 138 & Oberursel \\
\hline 5. Bulchok/Swat & $33.33 \mathrm{~N}, 71.53 \mathrm{E}$ & 349 & 1 & 2 & Oberursel \\
\hline \multicolumn{6}{|l|}{ India } \\
\hline 6. Kupwara & $34.31 \mathrm{~N}, 74.16 \mathrm{E}$ & 1811 & 5 & 60 & Verma et al. \\
\hline 7. Gurais & $34.37 \mathrm{~N}, 74.53 \mathrm{E}$ & 2364 & 5 & 60 & Verma et al. \\
\hline 8. Dras & $34.26 \mathrm{~N}, 75.46 \mathrm{E}$ & 2977 & 4 & 44 & Verma et al. \\
\hline 9. Srinagar & $34.08 \mathrm{~N}, 74.50 \mathrm{E}$ & 1768 & 5 & 60 & Verma et al. \\
\hline 10. Sonamarg & $34.18 \mathrm{~N}, 75.21 \mathrm{E}$ & 2740 & 6 & 80 & Oberursel / Verma et al. \\
\hline 11. Tral & $33.56 \mathrm{~N}, 75.10 \mathrm{E}$ & 2007 & 5 & 60 & Verma et al. \\
\hline 12. Rajouri & $33.23 \mathrm{~N}, 74.21 \mathrm{E}$ & 938 & 5 & 60 & Verma et al. \\
\hline 13. Kishtwar & $33.19 \mathrm{~N}, 75.48 \mathrm{E}$ & 1638 & 6 & 80 & Oberursel / Verma et al. \\
\hline 14. Katra & $33.03 \mathrm{~N}, 74.57 \mathrm{E}$ & 754 & 1 & 9 & Oberursel \\
\hline \multicolumn{6}{|c|}{ Himachal Pradesh } \\
\hline 15. Dalhousie & $32.32 \mathrm{~N}, 75.58 \mathrm{E}$ & 2036 & 5 & 60 & Verma et al. \\
\hline 16. Kangra & $32.05 \mathrm{~N}, 76.16 \mathrm{E}$ & 733 & 5 & 60 & Verma et al. \\
\hline
\end{tabular}

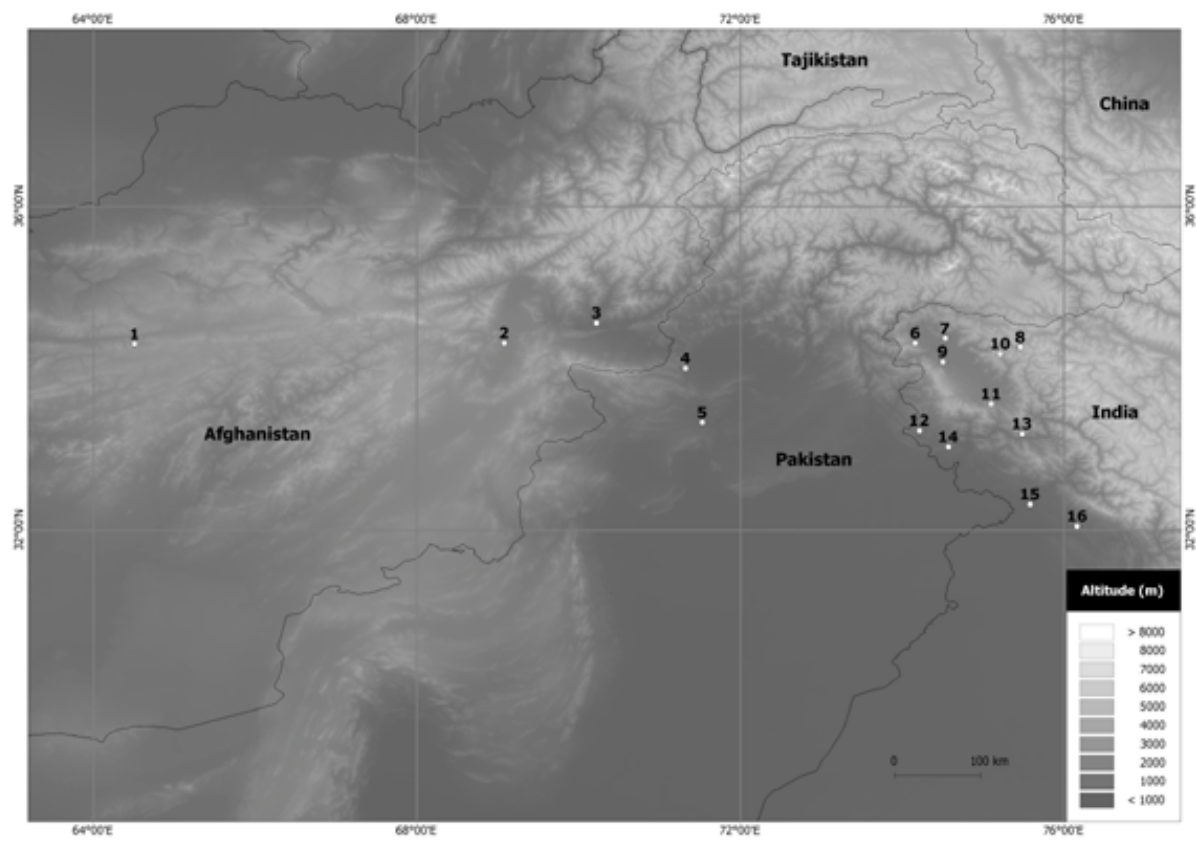

Figure 1. Distribution of localities, coordinates and altitudes from which worker honeybees of Apis cerana were measured. 


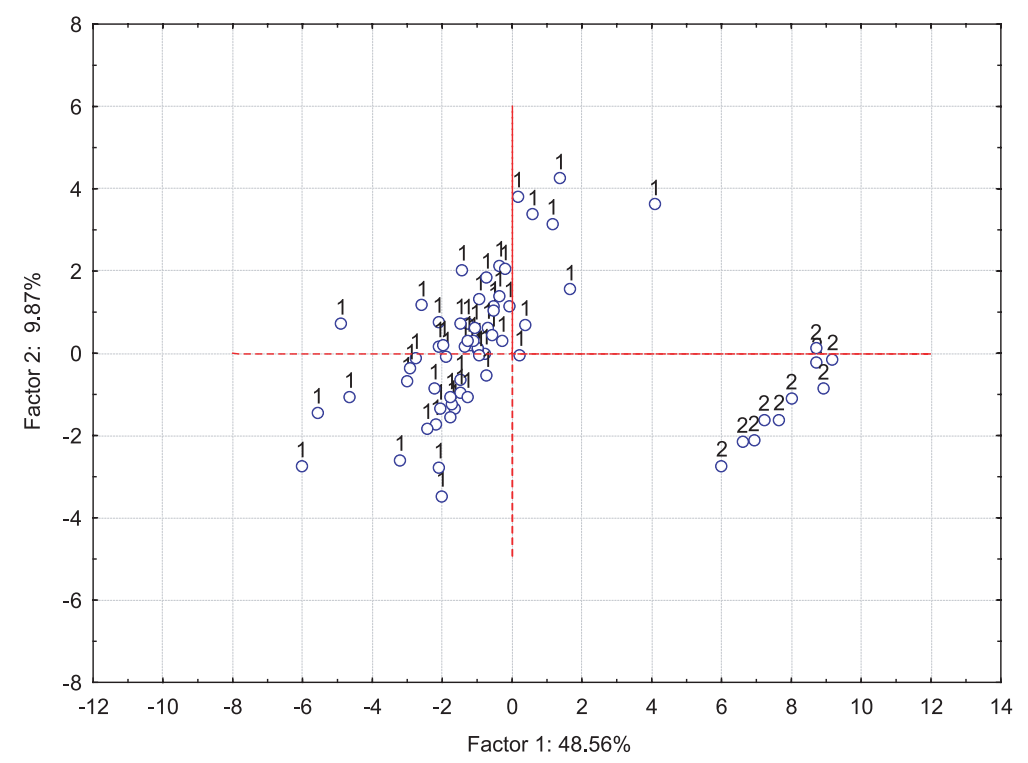

Figure 2. Factor analysis plot of the Hindu Kush Himalayan morphoclusters of A.cerana using 27 morphometric characters: morphocluster 1 comprises colonies from Afghanistan, Pakistan and the Kashmir region and morphocluster 2 comprises colonies from Himachal Pradesh.

study. Their Ruttner (1988) and Verma et al. (1989, 1994) numbers are given in round and square brackets, respectively, as follows: length of femur (5) [30], length of tibia (6) [31], metatarsus length (7) [32], metatarsus width (8) [33], tergite 3, longitudinal (9) [42], tergite 4, longitudinal (10) [45], sternite 3, longitudinal (11) [49], wax plate of sternite 3, longitudinal (12) [48], wax plate of sternite 3 , transversal (13) [46], distance between wax plates on sternite 3 (14) [47], sternite 6, longitudinal (15) [50], sternite 6 , transversal (16) [51], forewing, longitudinal (17) [5], forewing, transversal (18) [6], cubital vein, distance a (19) [7], cubital vein, distance b (20) [8], wing angle A4 (21) [9], wing angle B4 (22) [10], wing angle D7 (23) [11], wing angle E9 (24) [12], wing angle G18 (25) [13], wing angle I10 (26) [14], wing angle I16 (27) [15], wing angle K19 (28) [16], wing angle L13 (29) [17], wing angle N23 (30) [18], wing angle $\mathrm{O} 26$ (31) [19].

Morphometric measurements of honeybees from Sonamarg and Kishtwar were available from both databases thus allowing adjustments for different measurers. The measurements of the Oberursel database were adjusted to the somewhat larger Verma database by proportionally weighting the values so that the colony mean values of the 27 characters were the same for the two localities in common. Only minor adjustments were made: size-related charac- ter values from Oberursel were all slightly smaller (weights ranged from 1.024 to 1.067); angles of venation, on the other hand, were all slightly larger (weights ranged from 0.906 to 0.991 ).

\subsection{Data analysis}

Multivariate statistical analysis of the data included factor analysis using the principal components method of extraction, stepwise linear discriminant analysis, Wilks' lambda statistic for testing significant differences between the means of the characters entered into the discriminant functions and Levene's F statistic procedure for testing heterogeneity of variances (Johnson and Wichern, 1998; Rao, 1998).

\section{RESULTS}

In a factor analysis of the morphometric characters of worker honeybees from 68 colonies five factors with eigenvalues greater than one were isolated. Factor 1: size-related characters (5), (6), (9) to (19) and angle of venation (29) accounted for $48.6 \%$ of the variation; Factor 2: angles of venation (24) and (28) and sizerelated character (8) accounted for $9.9 \%$ of the 
variation; Factors 3, 4 and 5: angles of venation (22) and (23), (7.7\% variation); (21), (6.9\% variation); (30), (4.7\% variation), respectively. The factor loadings for each character had an absolute value greater than 0.64. A graph of the factor scores from factors 1 and 2 revealed two morphoclusters, with those colonies from localities 1-3 in Afghanistan, 4,5 in Pakistan and 6-14 in Kashmir forming one cluster (1) and those colonies from localities 15,16 in Himachal Pradesh forming a second cluster (2) (Fig. 2).

A forward stepwise discriminant analysis confirmed the two morphoclusters with $100 \%$ correct classification of the 58 colonies from Afghanistan, Pakistan and Kashmir with a posteriori probabilities equal to one for all colonies. Likewise, there was a $100 \%$ correct classification of the 10 colonies from Himachal Pradesh with a posteriori probabilities equal to one for all colonies. Four of the 27 morphometric characters which entered into the discriminant function in descending order of discriminating power are as follows: size-related characters (12), (13), (11) and wing angle (25). A significant difference was found among the vector means of the four clusters [Wilks' $\Lambda=0.0211$; $\mathrm{F}(4,63)=732.6, P<0.0001]$. The means and standard deviations of the 27 characters for each morphocluster are given in Table II.

The intercolonial variances at the 16 localities were determined using the first factor loadings. A significant difference was found between the intercolonial variances over all the localities (Levene's F $=3.27$ with $(15,52) \mathrm{df}, P=$ $0.0007)$ and significantly high variations were found at three localities: Bidiwa (3), Peshawar (4) and Rajouri (12).

\section{DISCUSSION}

The graph of the factor scores demonstrates the occurrence of two statistically distinct morphoclusters of $A$. cerana in the far western area of its distribution. The honeybees of the Hindu Kush in Afghanistan and Pakistan and in Kashmir, India form one morphocluster; while the bees of Himachal Pradesh, India form a second morphocluster (Fig. 2). The finding that the Hindu Kush/Kashmir bees are somewhat larger than those of Himachal Pradesh is in agreement
Table II. Means and standard deviations (sd) of 27 morphometric characters (measurements in $\mathrm{mm}$, angles in degrees) for two morphoclusters of Hindu Kush Himalayan A. cerana. Ruttner (1988) and Verma et al. $(1989,1994)$ numbers in round and square brackets, respectively.

\begin{tabular}{|c|c|c|c|c|}
\hline \multirow{3}{*}{ Character } & \multicolumn{4}{|c|}{ Morphocluster } \\
\hline & \multicolumn{2}{|c|}{$1(\mathrm{n}=58)$} & \multicolumn{2}{|c|}{$2(\mathrm{n}=10)$} \\
\hline & mean & $\mathrm{sd}$ & mean & $\mathrm{sd}$ \\
\hline (5) [30] & 2.59 & 0.04 & 2.44 & 0.02 \\
\hline (6) [31] & 3.22 & 0.05 & 3.09 & 0.03 \\
\hline (7) $[32]$ & 2.01 & 0.04 & 1.95 & 0.03 \\
\hline (8) [33] & 1.11 & 0.03 & 1.08 & 0.01 \\
\hline (9) [42] & 2.11 & 0.04 & 1.96 & 0.04 \\
\hline (10) [45] & 2.06 & 0.04 & 1.89 & 0.02 \\
\hline (11) [49] & 2.60 & 0.04 & 2.42 & 0.03 \\
\hline (12) $[48]$ & 1.24 & 0.03 & 1.51 & 0.01 \\
\hline (13) $[46]$ & 2.27 & 0.04 & 1.99 & 0.02 \\
\hline (14) $[47]$ & 0.31 & 0.04 & 0.20 & 0.01 \\
\hline (15) $[50]$ & 2.40 & 0.04 & 2.31 & 0.03 \\
\hline (16) $[51]$ & 2.91 & 0.04 & 2.59 & 0.01 \\
\hline (17) $[5]$ & 7.77 & 0.11 & 8.43 & 0.10 \\
\hline (18) $[6]$ & 3.08 & 0.05 & 2.84 & 0.02 \\
\hline (19) [7] & 0.57 & 0.02 & 0.54 & 0.01 \\
\hline (20) [8] & 0.16 & 0.01 & 0.14 & 0.00 \\
\hline (21) [9] & 33.12 & 1.08 & 32.37 & 0.41 \\
\hline (22) $[10]$ & 107.03 & 2.08 & 106.85 & 1.13 \\
\hline (23) [11] & 95.49 & 1.61 & 93.52 & 1.43 \\
\hline (24) [12] & 17.79 & 0.75 & 19.17 & 0.33 \\
\hline (25) [13] & 90.04 & 1.66 & 88.17 & 0.64 \\
\hline (26) $[14]$ & 43.18 & 1.46 & 43.43 & 0.98 \\
\hline (27) $[15]$ & 97.29 & 1.78 & 97.26 & 1.12 \\
\hline (28) [16] & 80.99 & 1.63 & 82.82 & 1.32 \\
\hline (29) & 13.02 & 0.62 & 15.76 & 0.32 \\
\hline (30) $[18]$ & 75.58 & 1.54 & 73.98 & 1.41 \\
\hline (31) $[19]$ & 32.33 & 1.79 & 31.57 & 1.17 \\
\hline
\end{tabular}

with previous observations (Verma et al., 1989; Hepburn et al. 2001).

The finding that the A. cerana of Himachal Pradesh formed a morphocluster distinct from the Kashmir group was in agreement with previous analyses of southern Himalayan bees (Hepburn et al., 2001). The formerly unknown group of $A$. cerana of the Hindu Kush is now seen to be part of the Kashmir morphocluster. The general results confirm the inference of Ruttner (1988) that the A. cerana of northern Afghanistan, Pakistan and India would form a compact group. The absence of morphometric 
data for the A. cerana of southwestern China precludes comment on possible affinities of these bees. However the extreme elevations of the Parmir and Himalayan mountain ranges constitute a barrier of several thousand $\mathrm{km}$ between the northern and southern populations of A. cerana.

A final point of interest concerns the distribution of the three high variance domains in the Hindu Kush/Kashmir morphocluster area. Significantly high intercolonial variances were obtained at Bidiwa (3) in the Nuristan area of Afghanistan, which is the juncture for three different climatic zones. Similarly, two different climatic zones converge on the areas around Peshawar (4) and Rajouri (12) (Müller, 1982). The convergence of zones of climatic change is interpreted as areas of ecological instability and this is consistent with the distribution of other high variance domains both in Asia (Hepburn et al., 2001) and Africa (Hepburn and Radloff, 1998).

Résumé - Affinités morphologiques d'Apis cerana de l'Indou Kouch et des régions asiatiques occidentales de l'Himalaya. Apis cerana Fabricius s'étend à travers toute l'Asie méridionale et sa limite occidentale est proche de l'Hindu Kush d'Afghanistan et du Pakistan. Pourtant jusqu'à présent, les abeilles de cette région n'ont pas été déterminées en raison d'un manque de spécimens. L'acquisition et la fusion de deux bases de données morphométriques pour toute la région ont permis d'effectuer une analyse morphométrique d'A. cerana afin de déterminer les affinités des deux populations. Au total 902 abeilles provenant de 68 colonies réparties en 16 localités (Tab. I, Fig. 1) ont été mesurées et les données morphométriques analysées par l'extraction des composantes principales, l'analyse discriminante linéaire pas à pas, la statistique lambda de Wilk et la statistique F de Levene.

Une représentation graphique des valeurs des facteurs a montré l'existence de deux groupes morphologiques (sous-espèce définie morphométriquement), ceux de l'Hindou Kouch et du Cachemire formant un premier groupe et ceux de l'Himachal Pradesh formant un autre groupe (Fig. 2). Une analyse discriminante pas à pas ascendante a confirmé les deux groupes morphologiques avec une classification $100 \%$ correcte et des probabilités a posteriori égales à un pour toutes les colonies des deux groupes morphologiques. Le tableau II donne les moyennes et les écarts-types pour chaque groupe morphologique. Les variances inter-colonies dans les 16 localités ont montré des différences significatives pour toutes les localités avec des valeurs hautement significatives dans trois localités : Bidiwa, Peshawar et Rajouri (Tab. I ; Fig. 1). Chacun de ces domaines de haute variance est associé à des points de jonction ou à des transitions entre plusieurs zones climatiques importantes. De telles régions de transition sont considérées comme des régions d'instabilité écologique ; cette interprétation est cohérente avec d'autres régions de forte variance en Asie et en Afrique.

Apis cerana / morphométrie / Asie occidentale / morphogroupe

Zusammenfassung - Morphometrische Ähnlichkeitsbeziehungen von Apis cerana des Hindukusch und der westasiatischen Regionen des Himalaya. Die westliche Grenze des sich über die gesamte Südasiatische Region erstreckenden Verbreitungsgebiets von $A$. cerana befindet sich nahe dem Hindukusch von Afghanistan und Pakistan. Die Ähnlichkeitsbeziehungen der Bienen dieser zwei Gebiete konnten allerdings nicht bestimmt werden, da bislang zu wenige Proben zur Verfügung standen. Eine zusammenfassende multivariate morphometrische Analyse beider Populationen wird nun durch die Zusammenfassung von zwei die gesamte Region abdeckenden morphometrischen Datenbanken ermöglicht. Insgesamt wurden 902 Bienen aus 68 Völkern von 16 Probenorten erfasst (Tab. I, Abb. 1) und die Daten durch Extraktion der Haupkomponenten, schrittweise Diskriminazanalyse sowie Wilks' Lambda und Levene's F Statistik untersucht.

Ein graphischer Faktorenplot zeigte zwei verschiedene Morphokluster (= morphometrisch definierte Subspezies), die Bienen des Hindu Kush und Kashmir bildeten einen Kluster, ein zweiter enthielt die Bienen von Himachal Pradesh (Abb. 2). Eine Diskriminanzanalyse unter schrittweiser Hinzunahme von Variablen bestätigte die zwei Morphokluster mit $100 \%$ korrekter Klassifikation und a posteriori Zuordnungswahrscheinlichkeiten von eins für alle Völker der beiden Morphokluster. Tabelle II gibt Mittelwerte und Standardabweichungen der Merkmale für beide Morphokluster an.

Die Varianzen innerhalb der Völker an den 16 Probenorten waren insgesamt unterschiedlich und waren an den drei Orten Bidiwa, Peshawar and Rajouri (Tab. I, Abb. 1) signifikant erhöht. Alle drei dieser Domänen hoher Varianz fielen mit Verbindungen oder Übergängen zwischen klimatischen Zonen zusammen. Solche Übergangszonen werden als Areale ökologischer Instabilität aufgefasst, eine Interpretation, die mit anderen Arealen hoher Varianz in Asien oder Afrika übereinstimmt.

Apis cerana / Honigbienen / Morphokluster / Westliches Asien 


\section{REFERENCES}

Hepburn H.R., Radloff S.E. (1998) Honeybees of Africa, Springer-Verlag, Berlin.

Hepburn H.R., Radloff S.E., Verma S., Verma L.R. (2001) Morphometric analysis of Apis cerana populations in the southern Himalayan region, Apidologie 32, 435-447.

Johnson R.A., Wichern D.W. (1998) Applied Multivariate Statistical Analysis, Fourth Edition, Prentice Hall, Upper Saddle River, New Jersey.

Maa T. (1953) An inquiry into the systematics of the Tribus Apidini or honeybees (Hymenoptera), Treubia 21, 525-640.
Müller M.J. (1982) Selected Climatic Data for a Global Set of Standard Stations for Vegetation Sciences, Junk, The Hague.

Rao P.V. (1998) Statistical Research Methods in Life Sciences, Brooks/Cole Publishing Company, Pacific Grove, CA.

Ruttner F. (1988) Biogeography and Taxonomy of Honeybees, Springer-Verlag, Berlin.

Verma L.R., Kafle G.P., Sharma A., Mattu V.K. (1989) Biometry of Apis cerana of Nepal Himalayas, in: Proc. 4th Int. Conf. Apic. Trop. Climates, pp. $458-465$.

Verma L.R., Mattu V.K., Daly H.V. (1994) Multivariate morphometrics of the Indian honeybee in the northwest Himalayan region, Apidologie 25, 203 223. 